\title{
THE EFFECT OF INTEGRITY AND WORK CULTURE ON EMPLOYEE PERFORMANCE IN THE REGIONAL FINANCIAL MANAGEMENT AGENCY OF BEKASI REGENCY
}

\section{Sri Wahyuningsih and Mubarok}

STIMA IMMI Jakarta

E-mail: yuni.wahyuningsih1205@gmail.com,barok_aox@yahoo.com

\begin{tabular}{l}
\hline ARTICLE INF0 \\
\hline Received: \\
July, 24th 2021 \\
Revised: \\
August, 9th 2021 \\
Approved: \\
August, 14 \\
th 2021
\end{tabular}
ABSTRACT

The main problem in this research is how big the influence of integrity and work culture on employee performance at the Bekasi District Financial Management Agency, either simultaneously or partially. The author's purpose of conducting this research is to determine and analyze the Integrity and Work Culture on Employee Performance and the magnitude of the Influence of Integrity and Work Culture on Employee Performance in the Regional Financial Management Agency of Bekasi Regency, either simultaneously or partially. The method used in this study is a method with a descriptive and verification approach. The population in this study were employees of the Regional Financial Management Agency of Bekasi Regency, amounting to 50 people, of which all of the population were sampled. The data in this study is primary data, where the data is obtained from respondents' answers to the questionnaires that the authors distribute. The results of the data analysis that the author has done, the results show that there is a simultaneous and partial influence of integrity and work culture on employee performance at the Bekasi Regency Financial Management Agency, but when viewed partially, work culture affectts employee performance more than integrity.

KEYWORDS Integrity, Work Culture, Employee Performance

\begin{tabular}{ll}
\hline & Sri Wahyuningsih and Mubarok. (2021). The Effect of Integrity and Work \\
& Culture on Employee Performance in the Regional Financial Management \\
& Agency of Bekasi Regency. Journal Eduvest. 1(8): $693-700$ \\
How to cite: & $2775-3727$ \\
E-ISSN: & https://greenvest.co.id/ \\
Published by: &
\end{tabular}




$\begin{array}{ll}\text { (c) (i) (-) } & \text { This work is licensed under a Creative Commons } \\ \text { Attribution-ShareAlike 4.0 International License }\end{array}$

\section{INTRODUCTION}

The Bekasi Regency Regional Financial Management Agency does not only exist at the top manager level, but there must also be a middle manager level and his subordinates (Marani, 2002). If only the top managers have high performance but their subordinates do not have high performance then the quality of service perceived by the community will be low. This is because in practice the implementers in the field are actually subordinates. Therefore, efforts to improve agency performance must cover all levels of the organization (Mamuaja, 2016).

The fact is that many leaders and state apparatus are not only difficult to change but also often ignore the moral values and work culture of the state apparatus (Hia, 2020). Based on an evaluation conducted by the Ministry of Administrative Reform, apart from having too many government organizations, many civil servants are unemployed, just pacing and reading newspapers until working hours are over (Aparatur \& Birokrasi, n.d.). Activities that show the nuances of busy work can only be seen in work units that "have projects". So it is not wrong if there are observers who state that Civil Servants (PNS) tend to be project-oriented rather than carrying out their routine tasks.

Along with that, from the fact that so far, employees at the Bekasi Regency Financial Management Agency almost never work and move in an impulsive or directed manner. They work arbitrarily with a way of working that only works, carelessly, chaotic, and the management function is almost non-existent, the integrity of the work is lost. Many working hours are not made effective with their job duties. The attitudes of working concisely, neatly, neatly, caringly, diligently and so on are not satisfactory. In addition, there is no awareness that work success is rooted in the values possessed and behavior that becomes a habit. For him the important thing is to be present and receive a salary. So that the service performance of the apparatus and supervision sector is still below the desired level of expectation (Rahmadani \& Wahyuni, 2018).

This shows that the integrity and work culture of civil servants is not strong enough and is still far from expectations (Supratman, 2018). Inadvertently or unconsciously, it seems that most civil servants have been immersed in the daily grind of enlarging the power, authority, role and teaching of physical targets while taking advantage of the opportunities between the gaps in formal provisions and convoluted administrative procedures of their own creation. .

The work integrity of the Civil Servants at the Regional Financial Management Agency of Bekasi Regency can also be said to be very low. It doesn't even meet the standards of a public servant. This can be seen from the morning apple which is held every day by the service/agencies. Regarding the level of integrity of employees, the leadership of the Regional Financial Management Agency of Bekasi Regency has tried to do various things to make employees have integrity. Such as asking employees to fill in the attendance list for apples, filling in attendance for arrival and going home. After that, he also made a letter of warning to employees who were judged to have no integrity at work.

Reprimand after reprimand continues, but in fact the behavior still exists and seems to continue to spread and spread among the employees. Because integrity is the main 
capital in building the nation and the region, so if we want to move forward, start with integrity in our work (Suwasono, 2010). This step is important in order to raise new awareness at work, that Civil Servants who do not have integrity in their work will be given sanctions according to the violations they have committed.

The government paradigm has changed, no longer making Civil Servants as people who must be served, but must serve the people (Lumentah, Posumah, \& Londa, 2018). It is enough for civil servants to be people who are served by the people. Let's change the mindset of all of us. Because all of this is also for the benefit of the people who have long been waiting for extra attention from their government (Murdani \& Kusmanto, 2014).

The integrity of employees plays an important role in carrying out tasks to produce high performance (Rani, Lambey, \& Pinatik, 2018). According to Mulyadi in (Nugrahadi \& Sukiswo, 2019) integrity is a quality that underlies trust public and is a benchmark for members in testing decisions that took it. in mandatory integrity a member to be honest and frankly without having Confidential delivery of service recipients.

In addition, organizations that have certain habits that can be said as organizational culture and can also be called work culture, where high integrity and a conducive integrated work culture are implanted are expected to increase the high performance of the organization. Repeatedly by employees in an organization. Violation of this habit does not have a strict sanction, but the actors of the organization have morally agreed that this habit is a habit that must be adhered to in the context of carrying out work to achieve organizational goals. Work culture will be useful in an organization when each employee gives each other advice from his co-workers, but the culture work will be bad if the employees in the agency release their respective egos because they think that they can work alone without the help of others.

To determine the extent to which changes are needed, the first step is to analyze the culture that lives in the work unit or organization to decide what needs to be changed and the second is to analyze work integrity in relation to performance.

\section{RESEARCH METHODS}

The method used in this research is descriptive and verification method. According to (Sugiyono, 2019) descriptive methods is used to describe or describe problems related to questions on independent variables, namely describing good corporate governance and profitability. While verification analysis is an analysis of models and evidence that is useful for finding the truth of the proposed hypothesis. With the method that has been stated, the author intends to collect historical data and observe carefully about certain aspects related to the problem under study so that data will be obtained that support the preparation of research reports. The data obtained is then processed, further analyzed the theoretical basis that has been studied so as to obtain an overview of the object and conclusions can be drawn regarding the problem under study.

The population in this study were employees of the Regional Financial Management Agency of Bekasi Regency, amounting to 50 people, of which all of the population were sampled. The data in this study is primary data, where the data is obtained from respondents' answers to the questionnaires that the authors distribute. 


\section{RESULTS AND DISCUSSION}

\section{A. Data Analysis Results}

Table 1 Recapitulation of Integrity Measurement

\begin{tabular}{llll}
\hline \hline No & Statement & $\begin{array}{l}\text { Interpretation } \\
\text { Number }\end{array}$ & Score \\
\hline \hline 1 & $\begin{array}{l}\text { Follow professional and institutional code of } \\
\text { ethics. }\end{array}$ & 3,26 & Enough \\
\hline \hline 2 & $\begin{array}{l}\text { Honest in using and managing resources } \\
\text { within the scope or authority. }\end{array}$ & 3,12 & Enough \\
\hline \hline 3 & $\begin{array}{l}\text { Take the time to ensure that what is being } \\
\text { done does not violate the code of ethics. }\end{array}$ & 3,22 & Enough \\
\hline \hline & $\begin{array}{l}\text { Take actions that are consistent with values } \\
\text { and beliefs. }\end{array}$ & 3,26 & Enough \\
\hline \hline 5 & $\begin{array}{l}\text { Talking about being unethical even if it } \\
\text { would hurt a colleague or close friend. }\end{array}$ & 3,09 & Enough \\
\hline \hline 6 & Honest in dealing with other people & 3,34 & Good \\
\hline \hline 7 & Openly admits to having made a mistake. & 3,78 & Good \\
\hline \hline 8 & $\begin{array}{l}\text { Be honest even though it can damage a good } \\
\text { relationship }\end{array}$ & 3,5 & Good \\
\hline \hline 9 & Always focus on carrying out the task & 3,42 & Good \\
\hline \hline & AVERAGE = 29,99/9 = 3,33 (enough) & & \\
\hline \hline
\end{tabular}

From the results of the table recapitulation above, it can be concluded that the average number of interpretations is 3.33 with a fairly good criteria assessment. This means that the integrity of the employees is going well even though it is not optimal, this is based on the indicators of the variables obtained from the respondents based on the distributed questionnaires.

This research is in accordance with theory of Planned Behavior (TPB) emphasized that how intentions are perceived it has a lot of impact on behavior someone, so the performance of the auditor is not seen from the results of the audit opinión issued but how about the auditor it has the intention to be honest and carrying out work and report accordingly with what was found (Arman, 2018).

From the results of the research, there are several things that must be improved regarding the integrity of employees, namely:

1. Follow the professional and institutional code of ethics.

2. Be honest in using and managing resources within the scope or authority.

3. Take the time to ensure that what is done does not violate the code of ethics.

4. Take actions that are consistent with values and beliefs.

Talking about being unethical even if it would hurt a colleague or close friend. Table 2 Recapitulation of Work Culture Measurement

\begin{tabular}{llll}
\hline \hline No & Statement & $\begin{array}{l}\text { Interpretation } \\
\text { Number }\end{array}$ & Score \\
\hline 1 & Learning new things & 3,50 & Good \\
\hline \hline
\end{tabular}




\begin{tabular}{|c|c|c|c|}
\hline 2 & $\begin{array}{l}\text { Maintain attitude and physical appearance } \\
\text { and keep the work environment neat and } \\
\text { clean }\end{array}$ & 3,46 & Good \\
\hline 3 & Carry out daily work tasks, I am on time & 3,48 & Good \\
\hline 4 & $\begin{array}{l}\text { In managing customers, always live up to } \\
\text { the function of providing service and } \\
\text { always behave customer oriented }\end{array}$ & 3,40 & Good \\
\hline 5 & $\begin{array}{l}\text { Encouraging colleagues to behave customer } \\
\text { oriented }\end{array}$ & 3,40 & Good \\
\hline 6 & $\begin{array}{l}\text { Act quickly, precisely, wisely and } \\
\text { responsibly in meeting customer needs }\end{array}$ & 3,34 & Good \\
\hline 7 & $\begin{array}{l}\text { Work with the plan and reference criteria } \\
\text { and carry out monitoring and evaluation }\end{array}$ & 3,34 & Good \\
\hline 8 & $\begin{array}{l}\text { Fully understand the duties and } \\
\text { responsibilities according to their roles and } \\
\text { functions }\end{array}$ & 3,50 & Good \\
\hline 9 & $\begin{array}{l}\text { Make/propose improvements to systems or } \\
\text { work habits that do not support the } \\
\text { accuracy and quality of work }\end{array}$ & 3,38 & Good \\
\hline 10 & $\begin{array}{l}\text { Learn the strengths and weaknesses of other } \\
\text { organizations }\end{array}$ & 3,22 & Enough \\
\hline 11 & $\begin{array}{l}\text { Flexible to face change for the good of the } \\
\text { organization }\end{array}$ & 3,16 & Enough \\
\hline 12 & $\begin{array}{l}\text { Observing and predicting the impact of an } \\
\text { event on the organization }\end{array}$ & 3,26 & Enough \\
\hline 13 & $\begin{array}{l}\text { Understand the goals of the agency, } \\
\text { understand positively and actively support } \\
\text { the achievement of agency goals }\end{array}$ & 3,20 & Enough \\
\hline 14 & $\begin{array}{l}\text { Empathize, respect others, and have a desire } \\
\text { to understand the work processes of other } \\
\text { units }\end{array}$ & 3,06 & Enough \\
\hline 15 & $\begin{array}{l}\text { Establish cross-sectoral cooperation on } \\
\text { issues that require } \\
\text { cooperation }\end{array}$ & 3,30 & Enough \\
\hline 16 & $\begin{array}{l}\text { The socialization given about understanding } \\
\text { the motto of excellent to caring is } \\
\text { appropriate to be applied }\end{array}$ & 3,18 & Enough \\
\hline 17 & $\begin{array}{l}\text { The work culture provided by the agency } \\
\text { through the existing media is appropriate }\end{array}$ & 3,36 & Good \\
\hline 18 & $\begin{array}{l}\text { The motto of cultural values needs to be } \\
\text { held in seminars or training. }\end{array}$ & 3,26 & Enough \\
\hline 19 & $\begin{array}{l}\text { Leaders have made efforts to introduce and } \\
\text { increase understanding of current cultural } \\
\text { values }\end{array}$ & 3,12 & Enough \\
\hline 20 & $\begin{array}{l}\text { Organizations need to internalize work } \\
\text { culture values into units/sections }\end{array}$ & 3,22 & Enough \\
\hline \multicolumn{4}{|c|}{ AVERAGE $=66,14 / 20=3,30($ enough $)$} \\
\hline
\end{tabular}




\section{Sri Wahyuningsih and Mubarok}

From the results of the table recapitulation above, it can be concluded that the average number of interpretations is 3.30 with a fairly good criteria assessment. This means that the work culture applied is running quite well but not optimal, this is based on indicators of variables obtained from respondents based on questionnaires and interview results. Work culture gives meaning to how members of the organization have a perception of the values in the organization that determine how members act and behave. Work culture can be actively encouraging or debilitating depending on the meaning of values, beliefs and norms (Rahayu, 2017).

From the results of the study, there are several things that must be improved regarding the employee's work culture, namely:

1. Study the weaknesses and strengths of other organizations

2. Flexibility to face change for the good of the organization

3. Observing and predicting the impact of an event on the organization

Table 3 Recapitulation of Performance Measurement

\begin{tabular}{llll}
\hline \hline No & Statement & $\begin{array}{l}\text { Interpretation } \\
\text { Number }\end{array}$ & Score \\
\hline \hline & $\begin{array}{l}\text { My work motivation is always increasing in } \\
\text { carrying out work assignments }\end{array}$ & Enough \\
\hline \hline 2 & $\begin{array}{l}\text { In carrying out my work I act quickly and } \\
\text { appropriately when faced with a crisis }\end{array}$ & 3,08 & Enough \\
\hline \hline 3 & $\begin{array}{l}\text { Motivated in carrying out the work so that } \\
\text { it can be done on time. }\end{array}$ & 3,34 & Enough \\
\hline \hline 4 & $\begin{array}{l}\text { In carrying out my work I try to create new } \\
\text { service products }\end{array}$ & 3,48 & Good \\
\hline \hline & $\begin{array}{l}\text { Strive to seek opportunities and be } \\
\text { proactive in advancing the organization }\end{array}$ & 3,78 & Good \\
\hline \hline 6 & Achievement of work & 3,50 & Good \\
\hline \hline 7 & quite proud at this point & Good \\
\hline \hline 8 & $\begin{array}{l}\text { Current work performance can improve } \\
\text { continuously. }\end{array}$ & 3,50 & Good \\
\hline \hline 9 & $\begin{array}{l}\text { Current working conditions can increase } \\
\text { work productivity and on time performance }\end{array}$ & 3,46 & Very good \\
\hline \hline 10 & $\begin{array}{l}\text { The current workplace situation can explore } \\
\text { the potential of existing employees }\end{array}$ & 3,48 & \\
\hline \hline AVERAGE = 34,30/10 = 3,43 (good) & & \\
\hline \hline
\end{tabular}

From the results of the table recapitulation above, it can be concluded that the average number of interpretations is 3.43 with a good criteria assessment. This means that employee performance runs quite optimally, this is based on indicators of variables obtained from respondents based on questionnaires and interview results. From the results of the study, there are several things that must be improved regarding employee performance, namely:

1. My work motivation is always increasing in carrying out work assignments

2. In carrying out my work I act quickly and appropriately when faced with a crisis 
Eduvest - Journal of Universal Studies

Volume 1 Number 8, August 2021 
3. Motivated in carrying out the work so that it can be done on time.

4. Current work performance can improve continuousl.

\section{CONCLUSION}

Based on the results of the research and processing of research data that the authors have done, it can be concluded that according to the respondents' perceptions of the integrity of the employees at the Bekasi Regency Financial Management Agency, it has been running quite well, this can be seen from the score of respondents' answers with an interpretation number value (WMS) of 3, 33 which is in the fairly good category. This means that the integrity of the employees of the Bekasi Regency Regional Financial Management Agency has been running quite well but not optimally. Work culture according to respondents' perceptions has also been going quite well, this can be seen from the respondent's answer score with an average score of interpretation (WMS) of 3.30 which is in the fairly good category. This means that the work culture that has been built at the Office of the Regional Financial Management Agency of Bekasi Regency has been running quite well but has not been optimal.

The performance of employees at the Regional Financial Management Agency of Bekasi Regency has been going well according to the perceptions of the respondents, it can be seen that the score of respondents' answers with an average score of interpretation (WMS) is 3.43 which is in the good category. This means that the performance of employees in carrying out their main functions and duties as a whole has been running in accordance with the vision, mission and goals of the institution. There is a simultaneous and partial influence of integrity and work culture on employee performance at the Bekasi Regency Regional Financial Management Agency, but when viewed partially, work culture affects employee performance more than integrity.

\section{REFERENCES}

Aparatur, Kementerian Pendayagunaan, \& Birokrasi, Reformasi. (N.D.). 2013.

Arman, S. (2018). Pengaruh Independensi, Integritas, Budaya Kerja, Kecerdasan Emosional Dan Gaya Kepemimpinan Terhadap Kinerja Auditor Kantor Akuntan Publik (Kap) Di Makassar. Jurnal Ilmiah Akmen, 15(2), 278-293.

Hia, Theori. (2020). Pengaruh Budaya Kerja Terhadap Komitmen Pegawai Negeri Sipil Di Dinas Komunikasi Dan Informatika Kabupaten Nias Barat.

Lumentah, Switry Varlein, Posumah, Johnny Hanny, \& Londa, Very. (2018). Akuntabilitas Kinerja Aparatur Sipil Negara Dalam Penyelenggaraan Pelayanan Publik Di Kantor Kecamatan Kawangkoan Kabupaten Minahasa. Jurnal Administrasi Publik, 4(50).

Mamuaja, Brejita. (2016). Analisis Efektivitas Penerapan Sistem Pengendalian Intern Terhadap Kinerja Instansi Pemerintah Di Dinas Pendapatan Kota Manado. Jurnal Emba: Jurnal Riset Ekonomi, Manajemen, Bisnis Dan Akuntansi, 4(1).

Marani, Yohanes. (2002). Motivasi Dan Pelimpahan Wewenang Sebagai Variabel Moderating Dalam Hubungan Antara Partisipasi Penyusunan Anggaran Dengan Kinerja Manajerial (Studi Empiris Pada Perguruan Tinggi Swasta Di Jayapura). Program Pascasarjana Universitas Diponegoro.

Murdani, Ojak, \& Kusmanto, Heri. (2014). Pengaruh Peraturan Pemerintah Nomor 53

Tahun 2010 Tentang Peraturan Disiplin Pns Terhadap Kepuasan Pelayanan Pada

Kantor Regional Vi Bkn. Jurnal Administrasi Publik: Public Administration 
Journal, 4(1), 101-115.

Nugrahadi, Eko Warsiyanto, \& Sukiswo, Wahyu Helmy Dimayanti. (2019). Pengaruh Independensi, Kompetensi, Objektifitas, Dan Integritas Terhadap Kualitas Audit Atas Sistem Informasi Berbasis Komputer Pada Kantor Akuntan Publik (Kap) Di Surabaya. Jurnal Rak (Riset Akuntansi Keuangan), 4(2), 42-50.

Rahayu, Endang Sri. (2017). Pengaruh Budaya Kerja, Integritas Dan Kepercayaan Terhadap Organizational Citizenship Behavior Pada Dosen Universitas Negeri Jakarta. Econosains Jurnal Online Ekonomi Dan Pendidikan, 15(1), 36-54.

Rahmadani, \& Wahyuni, Delvi. (2018). Types And Functions Of Address Terms Used By Ipmk-Sb "Kampar Students Studying In Padang." E-Journal Of English Language \& Literature, 7(1), 132-142.

Rani, Falentina K. G., Lambey, Linda, \& Pinatik, Sherly. (2018). Pengaruh Integritas, Kompetensi, Dan Profesionalisme Terhadap Produktivitas Kerja Karyawan Bagian Akuntansi Pada Pt. Bank Mandiri (Persero) Tbk Manado. Going Concern: Jurnal Riset Akuntansi, 13(3).

Sugiyono, Prof.Dr. (2019). Metode Penelitian Kuantitatif Kualitatif Dan R\&D. Bandung: Alfabeta.

Supratman, Dindin. (2018). Budaya Kerja Aparatur Sipil Negara Dalam Rangka Good Governance Menuju Birokrasi Berkelas Dunia. Jurnal Administrasi Publik, 14(2), 101-108.

Suwasono, Bagiyo. (2010). Budaya Kerja Dalam Pendidikan Tinggi Sebagai Bentuk Peningkatan Integritas Nasional. 